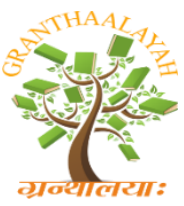

INTERNATIONAL JOURNAL OF RESEARCH GRANTHAALAYAH A knowledge Repository

Social

\title{
A STUDY OF LEGAL AWARENESS AMONG WOMEN TEACHERS
}

\author{
V. Manjula Devi ${ }^{1}$, Mrs. Ranjithamani ${ }^{2}$ \\ ${ }^{* 1}$ M.Ed Scholar, RVS College of Education, India \\ ${ }^{2}$ Assistant Professor, RVS College of Education, India
}

DOI: https://doi.org/10.29121/granthaalayah.v5.i5(SE).2017.1982

\begin{abstract}
The need of the hour that basic knowledge of laws should be imparted to a large section of educated population especially women who are the most sufferer section of the society. The Questionnaire was constructed and validated by the investigator. 200 school women teachers were selected as sample using stratified random sampling. The findings of the study reveal that there is a significant difference between awareness of legal rights among women school teachers on the basis of their subject and locality.
\end{abstract}

Keywords: Educated Population; Women; Legal Awareness; Population.

Cite This Article: V. Manjula Devi, and Mrs. Ranjithamani. (2017). "A STUDY OF LEGAL AWARENESS AMONG WOMEN TEACHERS." International Journal of Research - Granthaalayah, 5(5)SE, 122-126. https://doi.org/10.29121/granthaalayah.v5.i5(SE).2017.1982.

\section{Introduction}

Every country has prescribed legal Rights and Duties for its Citizen. The Citizens need to be aware about their Rights, the related legal provisions and processes. Coupled with this knowledge, they are also required to know how to realize their rights and entitlements. On the reverse side, there are certain duties and prohibitions which are cast upon people and that need to be observed so that they do not transcend the barriers and get into trouble for the same. Even after 65 years of independence a large section of Indian population remains uneducated and still larger is the population who has no knowledge of laws facing exploitation of all sorts. It is therefore, the need of the hour that basic knowledge of laws should be imparted to a large section of educated population especially women who are the most sufferer section of the society. Keeping this in mind, the researchers worked on the topic "A Study of Legal Awareness among Teacher" 


\section{Method}

The investigator has followed survey method for the present study. The Questionnaire was constructed and validated by the investigator. 200 school women teachers were selected as sample using stratified random sampling.

\section{Hypothesis: 1}

There will be a significant difference between awareness of legal rights among women school teachers on the basis of their subject

Table 1: Showing Mean, SD and t-test for awareness of legal rights among women $t$ school teachers on the basis of their subject

\begin{tabular}{|l|l|l|l|l|l|l|}
\hline Subject & N & Mean & $\begin{array}{l}\text { Std. } \\
\text { Deviation }\end{array}$ & $\begin{array}{l}\text { Std. Error } \\
\text { Mean }\end{array}$ & t-value & $\begin{array}{l}\text { Level of } \\
\text { Significance }\end{array}$ \\
\cline { 1 - 5 } Arts & 100 & 167.76 & 15.73 & 1.57 & \multirow{2}{*}{1.903} & Significant \\
\cline { 1 - 5 } Science & 100 & 171.90 & 15.03 & 1.50 & \\
\hline
\end{tabular}

The calculated t-value (1.903), which is significant at 0.01 levels, confirms that there is a significant difference in awareness towards legal rights among teachers on the basis of subject. Hence the stated hypothesis is accepted. To sum up arts and science differ significantly in their awareness towards legal rights. Science teachers possess better awareness towards legal rights than art group teachers.

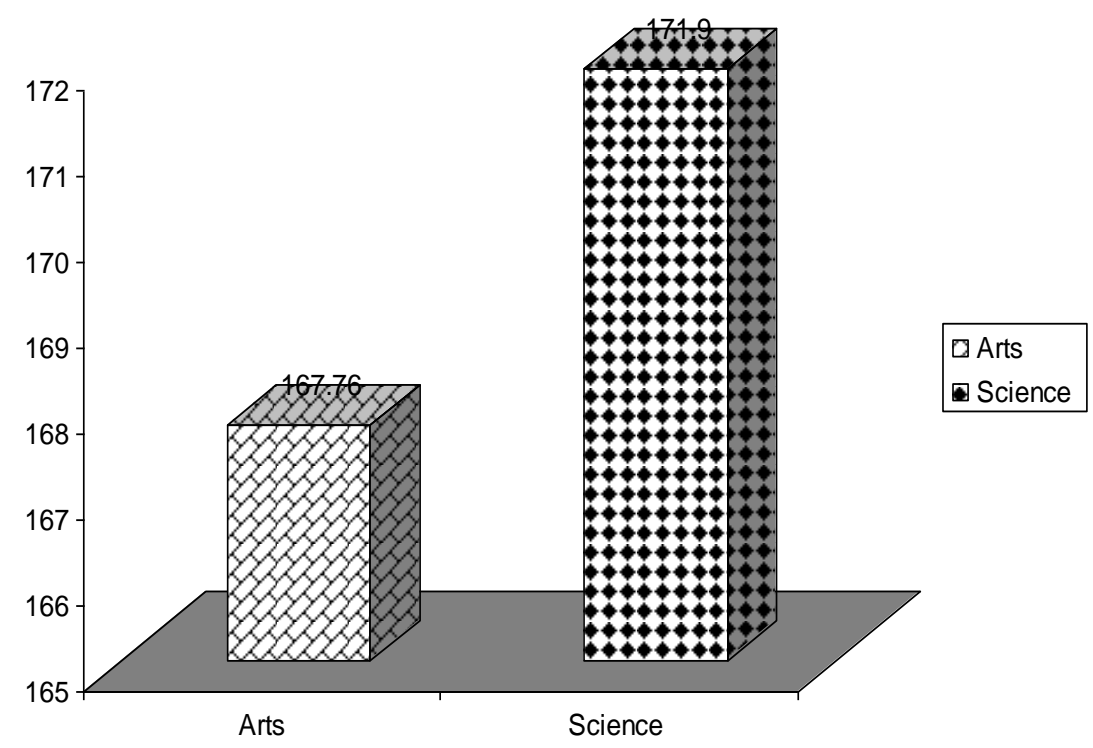

Figure 1: Howing Mean for awareness of legal rights among women $\mathrm{t}$ school teachers on the basis of their subject

\section{Hypothesis: 2}

There will be a significant difference between awareness of legal rights among women school teachers of the basis of their type of management 
Table 2: Showing Mean, SD and t-test for awareness of legal rights among women school teachers of the basis of their type of management.

\begin{tabular}{|l|l|l|l|l|l|l|}
\hline $\begin{array}{l}\text { Type of } \\
\text { College }\end{array}$ & N & Mean & $\begin{array}{l}\text { Std. } \\
\text { Deviation }\end{array}$ & $\begin{array}{l}\text { Std. Error } \\
\text { Mean }\end{array}$ & t-value & $\begin{array}{l}\text { Level of } \\
\text { Significance }\end{array}$ \\
\hline Government & 40 & 160.25 & 14.74 & 2.33 & \multirow{2}{*}{4.595} & $\begin{array}{l}\text { Not } \\
\text { Significant }\end{array}$ \\
\hline Private & 160 & 172.23 & 14.76 & 1.17 & & \\
\hline
\end{tabular}

The calculated t-value (4.595), which is significant at 0.01 level, confirms that there is a significant difference in awareness towards legal rights among teachers on the basis of type of school. Hence the stated hypothesis is accepted. To sum up government and private college do not differ significantly in their awareness towards legal rights.

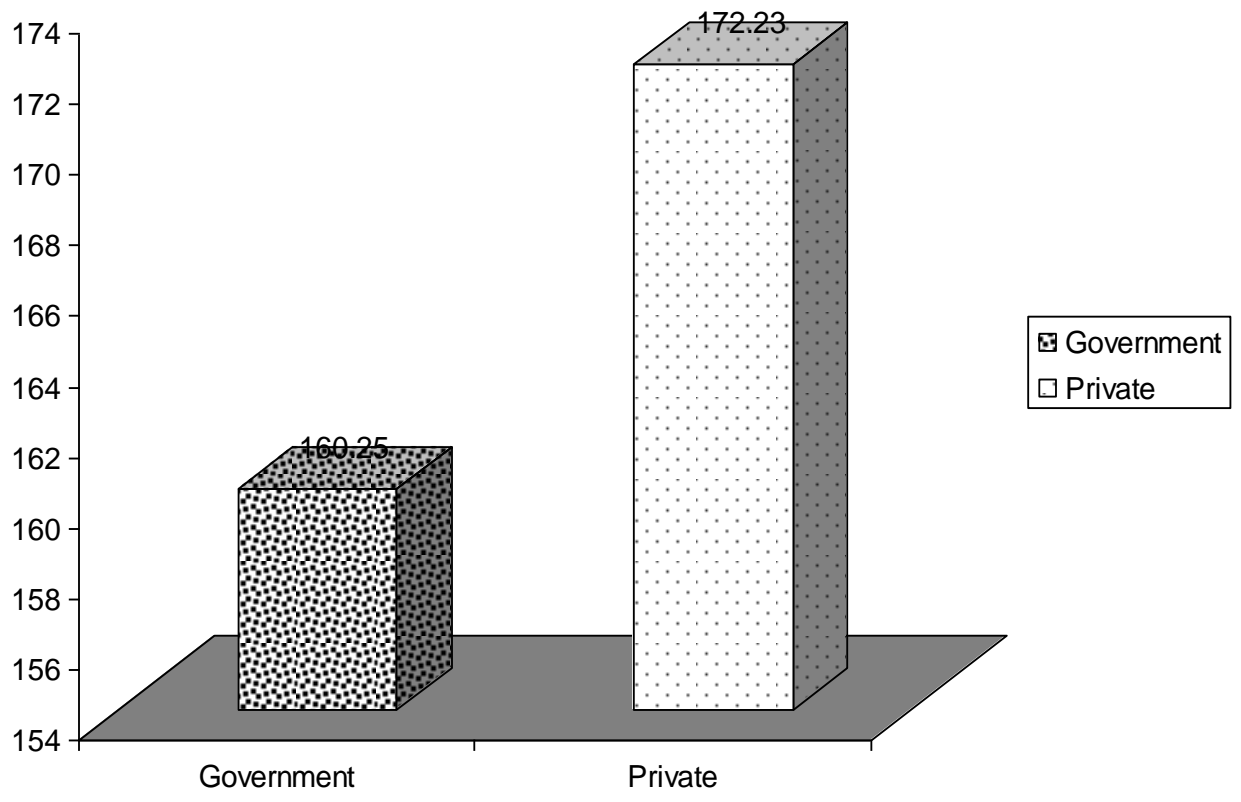

Figure 2: Showing mean for awareness of legal rights among women school teachers of the basis of their type of management

\section{Hypothesis :3}

There will be a significant difference between awareness of legal rights among women school teachers on the basis of their location of house

Table 3: Showing Mean, SD and t-test for awareness of legal rights among women school teachers on the basis of their location of house

\begin{tabular}{|l|l|l|l|l|l|l|}
\hline $\begin{array}{l}\text { Category of } \\
\text { College }\end{array}$ & N & Mean & $\begin{array}{l}\text { Std. } \\
\text { Deviation }\end{array}$ & $\begin{array}{l}\text { Std. Error } \\
\text { Mean }\end{array}$ & t-value & $\begin{array}{l}\text { Level of } \\
\text { Significance }\end{array}$ \\
\hline Rural & 100 & 163.17 & 15.47 & 1.55 & \multirow{2}{*}{1.725} & Significant \\
\cline { 1 - 4 } Urban & 100 & 176.49 & 12.37 & 1.24 & \\
\hline
\end{tabular}


The calculated t-value (1.725), which is significant at 0.01 level, confirms that there is a significant difference in awareness towards legal rights among teachers on the basis of category of school. Hence the stated hypothesis is accepted. To sum up rural and urban differ significantly in their awareness towards legal rights. Urban teachers possess better awareness towards legal rights than rural teachers.

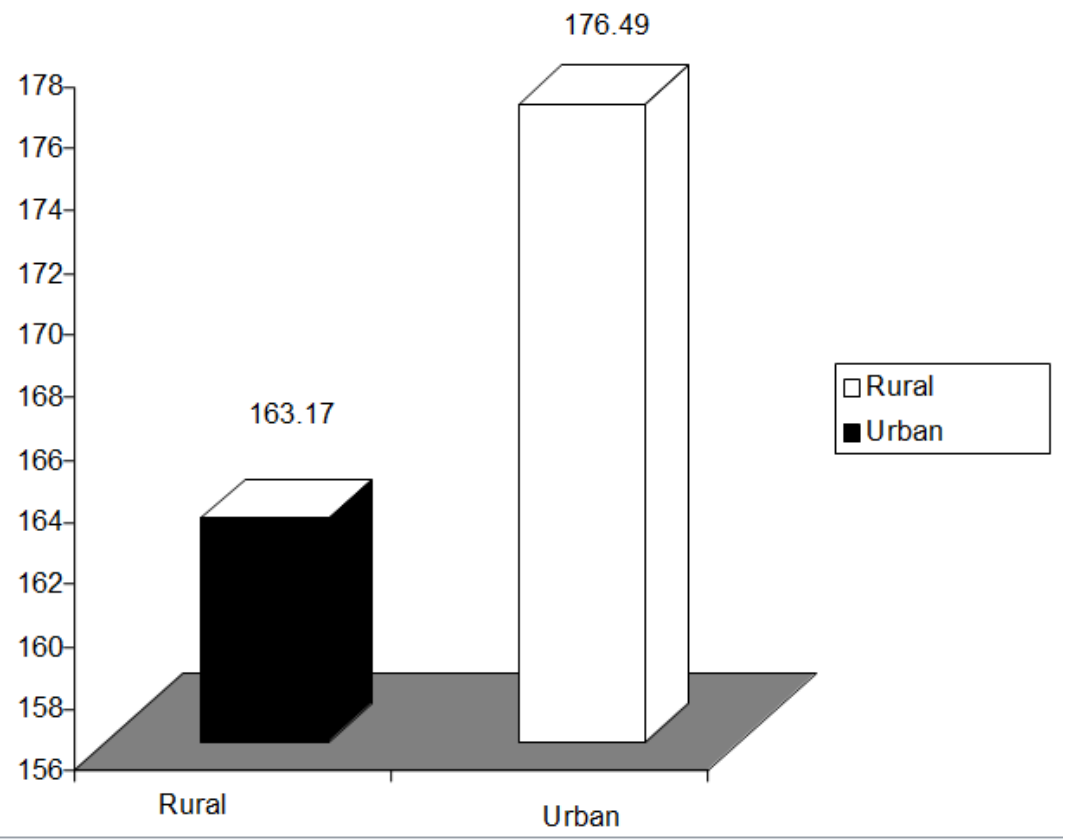

Figure 3: Showing mean for awareness of legal rights among women school teachers on the basis of their location of house

\section{Conclusion}

The findings of the study reveal that there is a significant difference between awareness of legal rights among women school teachers on the basis of their subject and locality. Science teachers possess better awareness towards legal rights than art group teachers. Urban teachers possess better awareness towards legal rights than rural teachers.

\section{References}

[1] Chatterji's study (1993): Of the three villages in Varanasi district of East U.P.

[2] Chowdhary Prem ,(1994) Widow Remarriage in Haryana.

[3] Fernandes, Walter (1991) Urbanisation, coping mechanisms and slum women's status.

[4] Golden, S. A. R. (2011). Problems and Prospectus of Distance Learning. Bharathidhasan University, 343, 344.

[5] Golden, S. A. R. (2011). Strategy For Success Of Human Beings:-Time Management. Department Of BBA, St. Joseph's College, Trichy, 388, 390.

[6] Golden, S. A. R. (2016). RURAL STUDENTS'ATTITUDE TOWARDS ENGLISH AS MEDIUM OF INSTRUCTION IN HIGHER EDUCATION-AN ANALYSIS. International Journal of Research, 3, 1-10.

[7] Golden, S. A. R. (2017). Attitude of Students and Teachers towards E-Learning-An Analysis. Recent Research in Social Science \& Humanities, 1, 5-10. 
[8] Golden, S. A. R. (2017). Recent Research in Social Sciences \& Humanities. EduPedia Publications (P) Ltd.

[9] Pathania Sunita (1996) Women's Movement in State of Haryana : Problems and challenges.

[10] Regi, S. B., \& Golden, S. A. R. (2014). A Study On Educational Loan Availed By Students In Trichy City. Journal Of International Academic Research For Multidisciplinary (Jiarm), 2 (1).

[11] Regi, S. B., \& Golden, S. A. R. (2014). A Study On Attitude Of Employee Towards Working Environment With Special Reference To RR Pvt Ltd. Review Of Research, 2

(2), 1,5 .

[12] Sarkar Latika (1994) Rape: A human rights versus a patriarchal interpretation:

[13] Sehgal Berendrapal Singh (1989) Law, Woman and Population in India. 